\title{
Corrigendum: Optimization of Agroinfiltration in Pisum sativum Provides a New Tool for Studying the Salivary Protein Functions in the Pea Aphid Complex
}

\author{
Endrick Guy ${ }^{1}$, Hélène Boulain ${ }^{1}$, Yoann Aigu ${ }^{1}$, Charlotte Le Pennec ${ }^{1}$, Khaoula Chawki ${ }^{1}$, \\ Stéphanie Morlière ${ }^{1}$, Kristina Schädel ${ }^{2}$, Grit Kunert ${ }^{2}$, Jean-Christophe Simon ${ }^{1}$ and \\ Akiko Sugio ${ }^{1 *}$ \\ 'INRA, UMR1349, Institute of Genetics, Environment and Plant Protection, Le Rheu, France, ${ }^{2}$ Department of Biochemistry, \\ Max Planck Institute for Chemical Ecology, Jena, Germany
}

Keywords: pea aphid, Acyrtosiphon pisum, Leguminosae, agroinfiltration, salivary proteins, biotypes, host specialization, effector

\section{A corrigendum on}

Optimization of Agroinfiltration in Pisum sativum Provides a New Tool for Studying the Salivary Protein Functions in the Pea Aphid Complex

by Guy, E., Boulain, H., Aigu, Y., Le Pennec, C., Chawki, K., Morlière, S., et al. (2016). Front. Plant Sci. 7:1171. doi: 10.3389/fpls.2016.01171

Corrigendum on Supplemental Table 2.

\section{OPEN ACCESS}

Edited and reviewed by: Jyoti Shah

University of North Texas, USA

*Correspondence:

Akiko Sugio

akiko.sugio@inra.fr

Specialty section:

This article was submitted to

Plant Biotic Interactions,

a section of the journal

Frontiers in Plant Science

Received: 19 December 2016 Accepted: 21 December 2016

Published: 10 January 2017

Citation:

Guy E, Boulain H, Aigu Y, Le Pennec C, Chawki K, Morlière $S$, Schädel K, Kunert G, Simon J-C and

Sugio A (2017) Corrigendum:

Optimization of Agroinfiltration in

Pisum sativum Provides a New Too

for Studying the Salivary Protein

Functions in the Pea Aphid Complex.

Front. Plant Sci. 7:2046.

doi: 10.3389/fp/s.2016.02046
In the original article, description of helper plasmids in C58C1 (pGV2260) and GV3101 (pMP90) were missing. The correct information of these two strains appears below. The authors apologize for the missing information. This error does not change the scientific conclusions of the article in any way.

\begin{tabular}{|c|c|c|}
\hline Bacteria & Features & References or sources \\
\hline \multicolumn{3}{|l|}{ BACTERIA } \\
\hline $\begin{array}{l}\text { Agrobacterium } \\
\text { tumefaciens } \mathrm{C} 58 \mathrm{C} 1\end{array}$ & Rif $^{\mathrm{r}}$, harbors pGV2260 (pTiB6S3 $\left.\Delta \mathrm{T}-\mathrm{DNA}\right)$ & Deblaere et al., 1985 \\
\hline $\begin{array}{l}\text { Agrobacterium } \\
\text { tumefaciens GV3101 }\end{array}$ & Rif $^{\mathrm{r}}$, harbors pMP90 (pTiC58 $\left.\Delta \mathrm{T}-\mathrm{DNA}\right)$ & $\begin{array}{l}\text { Koncz and Schell, } \\
1986\end{array}$ \\
\hline
\end{tabular}

\section{REFERENCES}

Deblaere, R., Bytebier, B., De Greve, H., Deboeck, F., Schell, J., Van Montagu, M., et al. (1985). Efficient octopine Ti plasmid-derived vectors for Agrobacterium-mediated gene transfer to plants. Nucleic Acids Res. 13, 4777-4788. doi: 10.1093/nar/13.13.4777

Koncz, C., and Schell, J. (1986). The promoter of TL-DNA gene 5 controls the tissue-specific expression of chimeric genes carried by a novel type of Agrobacterium binary vector. Mol. Gen. Genet. 204, 383-396. doi: 10.1007/BF00331014

Conflict of Interest Statement: The authors declare that the research was conducted in the absence of any commercial or financial relationships that could be construed as a potential conflict of interest.

Copyright (C) 2017 Guy, Boulain, Aigu, Le Pennec, Chawki, Morlière, Schädel, Kunert, Simon and Sugio. This is an open-access article distributed under the terms of the Creative Commons Attribution License (CC BY). The use, distribution or reproduction in other forums is permitted, provided the original author(s) or licensor are credited and that the original publication in this journal is cited, in accordance with accepted academic practice. No use, distribution or reproduction is permitted which does not comply with these terms. 